\title{
INTERNATIONAL AND NATIONAL FRAMEWORKS OF EQUAL ECONOMIC INDEPENDENCE FOR WOMEN AND MEN
}

\author{
Gardasevic Jovana ${ }^{1}$ \\ Ignjatijevic Svetlana ${ }^{2}$
}

\begin{abstract}
Economic independence enables individuals to have control over their own life for the purpose of personal and professional prosperity. The principle of equal pay and equality in work engagement is included in the EU treaties, respectively the equality is one of five values on which the European Union has been founded. In this paper we tried to answer the question whether "equal pay for work of equal value" is applied in practice? For that reason, the subject of our research is the analysis of the problem of gender inequality in order to point out the differences in employment rates and salaries in Serbia as well as in the EU countries. We analyzed the key documents, proposed some measures and pointed out the strategies that aim to support and address issues of gender inequality. In order to build an economically and socially developed society, Serbia, being on its path of European integrations, should pay particular attention to the issue of gender equality, further amending the legal framework and ensuring the inclusion of all aspects of gender equality in development policies.
\end{abstract}

Keywords: gender equality / gender inequality / economic independence / employment rate / pay gap

\footnotetext{
${ }^{1}$ Univerzitet Privredna akademija u Novom Sadu, Fakultet za ekonomiju i inženjerski menadžment u Novom Sadu, Cvećarska 2, Novi Sad, 021 469 513, gardasevic.jovana@gmail.com

2 Univerzitet Privredna akademija u Novom Sadu, Fakultet za ekonomiju i inženjerski menadžment u Novom Sadu, Cvećarska 2, Novi Sad, ceca@fimek.edu.rs
} 


\section{INTRODUCTION}

The European Union's achievements in fostering equality between women and men have recently helped change the lives of many European citizens for the better and provide the foundation on which we now have to build a genuinely genderequal society for the purpose of common prosperity.

In 2011, The European Union passed a document called: The Strategy for equality between women and men 2010 - 2015, which has to deal with these issues and has a significant impact on many other national polices of member states and future member states - like Serbia. Besides the legislative framework, Serbia has developed many different programs, frameworks, strategies and other documents in order to regulate and support this topic but one of the most important is The National Strategy for improving the position of women and promoting gender equality.

Economic independence is a prerequisite for enabling both women and men to exercise control over their lives and to make genuine choices for the purpose of personal and professional prosperity.

The principle of equal pay for men and women for work of equal value is enshrined in the EU Treaties but in practice it is a bit different. When it comes to women, the barriers to employment are also reflected in higher inactivity rates and higher longterm unemployment rates. It is known that the works in which women are engaged are paid less than the ones in which men are engaged, and they also continue to take up different types of jobs..

So, gender roles affect all areas of life including education, employment, family, health, etc. The precondition of economic development is social stability, which is based on a policy of equal opportunities, solidarity, social inclusion and social justice for everyone. Balanced economic development is not possible without adequate use of female human resources, so it is essential to take specific measures to encourage women in greater involvement in the market economy.

\section{FRAMEWORKS THAT REGULATE GENDER EQUALITY ISSUES}

\section{European sources of gender equality}

The question of the equality between men and women is one of those which date back to the beginning of the establishment of the community that we could find in the first European contracts like the Treaty of Rome from 1957 or The Lisbon Treaty from 2007. 


\section{The first strategic pillar}

The first strategic pillar of gender equality policies is found in the basic treaties and Charter. The Charter of Fundamental Social Rights of Workers, known as the Social Charter is considered as a political instrument that contains moral obligations which should guarantee that certain social rights will be respected (Radić, 2007, p.233). The Charter is determined by a set of 12 fundamental social rights and one of them deals with the issue of equality between men and women. ${ }^{3}$ The Amsterdam Treaty adopted a new clause that reinforces the principle of non-discrimination, which is closely associated with equality in providing opportunities. The Treaty of Amsterdam explicitly includes equality between women and men as the general objectives of the EU. The contract also defines human rights, particularly the principle of equal treatment for women and men, the guarantee of equal pay for work of equal value and the prohibition of discrimination on grounds of sex (Šijački, 2008, p. 31).

\section{The second strategic pillar}

The second strategic pillar of gender equality policies are different action programs. Topics that are covered by these action programs were related to elimination of existing inequalities that affect women in professional life, promotion of gender equality in employment, involvement of women in decision-making processes, and so on. The issue of Gender equality in external actions today is contained in: European Neighborhood Policy (ENP), Convention on the Elimination of all Forms of Discrimination against Women, Beijing Platform of Action and the Cairo Program of Action, as foreseen in the EU Plan of Action on Gender Equality and Women's Empowerment in Development (2010-2015). The Beijing Platform for Action is an agenda for women empowerment that reaffirms the fundamental principle whereby the human rights of women and the girl child are an inalienable, integral and indivisible part of universal human rights.

The twelve areas of concern of the BPFA are: 1 . Women and Poverty; 2. Education and Training of Women; 3. Women and Health; 4. Violence against Women; 5. Women and Armed Conflict; 6. Women and the Economy; 7. Women in Power and Decision-making; 8. Institutional mechanisms for the advancement of Women; 9. Human Rights of Women; 10.Women and the Media; 11. Women and the

\footnotetext{
3 The right of women and men to equal treatment. This equality must be guaranteed. Equality of opportunity must be more developed to complement full equality in the legal position.
} 
Environment; 12.The Girl Child (Strategy for Equality between women and men $2010-2015$, p. 28-29).

\section{The third strategic pillar}

The third strategic pillar of gender equality policies is gender mainstreaming. The most precise definition of this term is given in the Final Report of the Council of Europe, 1998., by groups of specialists for mainstreaming: "Gender mainstreaming is the (re)organization, improvement, development and evaluation of policy processes so that a gender equality perspective is incorporated in all policies at all levels and at all stages by the actors who are involved in decision-making”. Bearing this definition in mind it becomes clear that the idea of gender mainstreaming is a radical reinvent, restructure and re-branding of gender policies, strategies and theories (Walby, 2005, p. 321). As such, gender mainstreaming epitomizes many dilemmas of contemporary feminist theory and practice, and potentially provides new horizons in resolving these tensions (Verloo, 2001; Walby 2005; Woodward, 2001).

The European strategy for smart, sustainable and inclusive growth - Europe 2020 also deals with the issue of inequality, especially with the problem of women unemployment through broader framework. ${ }^{4}$

The Strategy for equality between women and men 2010 -2015 provides a coordinated framework for promoting gender equality in all policies of the Union, with five priority areas:

- Equal economic independence for women and men;

- Equal pay for work of equal value;

- Equality in decision-making;

- Dignity, integrity and an end to gender-based violence and

- Promoting gender equality beyond the EU (Mid - term review of the Strategy for equality between women and man 2010 -2015, p.3).

\footnotetext{
${ }^{4}$ According to Europe 2020, the employment rate of the population aged 20-64 should increase from the current $69 \%$ to at least $75 \%$, including through the greater involvement of women, older workers and the better integration of migrants in the work force.
} 
The Strategy adopted in 2010 contains 24 key actions 5 .

\section{Serbian sources of gender equality}

The Republic of Serbia is a signatory to a number of important and binding international documents which guarantee equality between women and men and prohibit discrimination based on sex. Among these documents the most important are: Universal Declaration of Human Rights; the Convention on the Elimination of All Forms of Discrimination against Women - CEDAW; European Convention for the Protection of Human Rights and Fundamental Freedoms; the European Social Charter and Council of Europe Convention on preventing and combating violence against women and domestic violence; EU Charter of Fundamental Rights. National sources of gender equality are: The Constitution of the Republic of Serbia (2006); The Gender Equality Law (2009);

The National Strategy for improving the position of women and promote gender equality (2009) (Women and men in the Republic of Serbia, 2014, p. 5).

Gender equality means equal participation of women and men in all areas of public and private sector, in accordance with the generally accepted rules of international law, ratified international treaties, the Constitution of the Republic of Serbia and other laws, and all people are bound to respect them (The Gender Equality Law, 2009). The modernization and Europeanization of the Republic of Serbia will be significantly promoted by the policy of equal opportunities for achieving gender equality in all areas of society development and strategic partnership between women and men (National Strategy for improving the position of women and promoting gender equality, article 2.2).

\section{EQUAL ECONOMIC INDEPENDENCE FOR WOMEN AND MEN - DOES IT EXIST IN PRACTICE?}

\section{What does the Employment Rate say?}

Employment, as a term used to measure the number of people employed, enjoys a broad definition within the labor force framework. It includes people at work, even if only for one hour during the reference period, and also people temporarily absent from work. In line with the labor force framework, the international defini-

\footnotetext{
5 In addition, the Staff Working Document accompanying the Strategy lists of more than 128 individual actions.
} 
tion of employment is based on a short reference period (one week or one day) and on the principle that a person must have been engaged in some economic activity during that reference period to be considered as employed (Hussmannset al., 1990, p. 69). The employment rate represents employed persons as a percentage of the population in the same age group. The employment status is measured according to the definition of the International Labor Organization. It should be noted that the employment situation of individuals depends on the availability of jobs as well as the decision/willingness to work among the population (Eurostat News Release: Employment rate of people aged 20 to 64 in the EU up to 69.2\% in 2014, 2015, p. 5).

Over the past decade, more women have become involved in full-time and, particularly, in part-time work. However, the percentage of women in employment in $2014(63.5 \%)$ is still 11.5 percentage points (pp) off the Europe 2020 target for total employment and the rate for men (both $75 \%$ ). Having a paid job is, in general, a necessary condition of financial independence, but unemployment rose steeply for both women and men during the crisis and shows no signs of falling - a whole generation has been affected. The rate of those 'not in education, employment or training' (NEET) has consistently been higher for women since before the crisis. The proportion of inactive young women, i.e. those who are not employed and are not looking for a job, remains double that of young men. Improving women's position in the economy has always been closely linked with finding ways of reconciling work and family life (Report on equality between women and men, 2014, p. 7).

Employment rates of men and women continued to vary considerably in many member states in 2014. The difference between the employment rate of women and that of men aged 20-64 was lowest in Finland (72.1\% for women vs. $74.0 \%$ for men, or -1.9 percentage points), Lithuania (-2.5 pp), Latvia and Sweden (both $-4.6 \mathrm{pp}$ ). At the opposite end of the scale, the largest difference between the employment rate of women and that of men was observed in Malta $(51.9 \%$ for women vs. $80.3 \%$ for men, or $-28.4 \mathrm{pp})$. Big gaps were also recorded in Italy (-19.4 pp), Greece (-18.3 pp), the Czech Republic (-17.5 pp) and Romania (-16.7 pp). At EU level, the difference between the employment rate of women aged 20-64 (63.5\%) and that of men aged 20-64 (75.0\%) was - 11.5 pp in 2014, compared with $-17.3 \mathrm{pp}$ in 2002 (Eurostat News Release: Employment rate of people aged 20 to $64 \mathrm{in}$ the EU up to $69.2 \%$ in 2014,2015 , p. 2).

The unemployment rate in Serbia is one of the highest in Europe. Unemployment rates range from $21 \%$ to $30 \%$, depending on the method of calculation. Position of unemployed women is determined by weak prospects for permanent employment, low and irregular payment of compensation for people out of work, not many 
chances for retraining and professional reorientation and a high probability that they will engage in unpaid work at home or work in the "gray economy" (Gender inequalities in the labor market of Serbia and European integration incentives, 2009, p. 13). According to the data from the Republic Institute for Statistics and Labor Force Survey, for the first quarter of 2015 , employment rate for men is $56.3 \%$ and $43.5 \%$ for women, while the unemployment rate for men is $19.1 \%$ and $20.8 \%$ for women (for the population of working age 15-64); employment rate for men is $48.1 \%$ and $34.4 \%$ for women, while the unemployment rate for men is 18.4 $\%$ and $20.3 \%$ for women, for the population of working age 15-24 (Labor Force Survey, 2015).

The results confirm the existing problem of insufficient involvement of women in the labor market of the Republic of Serbia. The reasons for that are numerous. These data led to the conclusion that in practice there is a tremendous employment gap between men and women in EU countries as well as in the Republic of Serbia which brings women in the position of unequal economic independence. Despite the fact that there is a growing number of women with tertiary education, in high positions, at decision-making levels and in political life, facts and statistical data show that women are still below the percentage of men when it comes to employment in both the private and the public sector. Many authors justified that fact by the frequent absence of women during their professional careers mostly due to motherhood. All the most common and potential causes of this inequality will be processed in the next section.

\section{What does the Gender Pay Gap say?}

Differences in wages between men and women have been the focus of attention of social scientists and policy makers for decades (Chevalier, 2006, p. 1). What makes sex differences in earnings? We will list some of them and be more focused on statistical data related to these differences. The differences can be structural and behavioral. Wood et al. (1993) mentioned that the major issue in human capital explanations of the sex-based wage gap is that women do the bulk of child rearing, and so acquire less experience and fewer job-related skills (human capital) than do men, and that these sex differences in human capital account for the wage gap (Mincer \& Polachek 1974; Becker 1985). In Wood et.al (1993), the authors speculated that women's access to high-paying positions is limited by statistical discrimination on the part of employers. Employers, who have imperfect information about potential employees, use sex to predict future work commitment and the likelihood that a worker will quit or take time off. Since women, on average, have 
more career interruptions than men, employers may hesitate to hire or promote women to jobs that require a long period of training and acquisition of firm-specific human capital (Lazear \& Sherwin, 1990).

When it comes to the behavioral approach to the pay gap, then some crucial factors are: Leadership, motivation, self-esteem, aggression, beauty and cleanliness are among the traits positively correlated with wages (Groves Osborne et al., 2001). Other determinants of the gender wage gap could be that women may have lower expectations, a greater dislike for negotiation (Babcock \& Laschever, 2003) and competition (Niederle \& Vesterlund, 2005) which would lead to lower reservation wages.

The gender pay gap measuring the difference in average gross hourly earnings between men and women across the whole economy and all establishments (Gender Pay Gaps in the European Labor Markets-measurements, analysis and policy implications, 2003, p. 7).

The gender pay gap, which refers to the difference between the wages earned by women and by men, is one of the key indicators of women's access to economic opportunities and undoubtedly one of the most persistent labor market characteristics globally (Avlijaš et al., 2013, p.9). In this paper we only give the facts which prove the existence of gender inequality in the field of economic independence. So, what does practice say?

In the European Union for every euro men get paid, women get paid only 84 cents. Even in the same occupation and with the same education level, women tend to be paid less than their male counterparts (Report on equality between women and men, 2014, p. 14). In 2013 in the EU member states, the gender pay gap was less than $10 \%$ in Slovenia (3.2\%), Malta (5.1\%), Poland (6.4\%), Italy (7.3\%), Croatia (7.4\%), Luxembourg (8.6\%), Romania (9.1\%) and Belgium (9.8\%). At the opposite end of the scale, the gender pay gap was over 20\% in Estonia (29.9\%), Austria (23.0\%), the Czech Republic (22.1\%) and Germany (21.6\%). Compared with 2008 , the gender pay gap dropped in 2013 in the majority of EU member states. The most noticeable decreases between 2008 and 2013 were recorded in Lithuania (from $21.6 \%$ in 2008 to $13.3 \%$ in 2013 , or -8.3 percentage points), Poland (-5.0 pp), the Czech Republic and Malta (both $-4.1 \mathrm{pp}$ ) and Cyprus (-3.7 pp). In contrast, the gender pay gap has risen between 2008 and 2013 in nine member states, with the most significant increases being observed in Portugal (from 9.2\% in 2008 to $13.0 \%$ in 2013 , or +3.8 percentage points), Spain (+3.2 pp), Latvia (+2.6 pp), Italy (+2.4 pp) and Estonia (+2.3 pp). At EU level, the gender pay gap has decrea- 
sed slightly, from $17.3 \%$ in 2008 to $16.4 \%$ in 2013 (Eurostat News Release: Women earned on average $16 \%$ less than men in 2013 in the EU, 2015, p. 2).

Analysis of Serbian Labor Force Survey data found that employed women in Serbia are better qualified yet earn less than men. A woman with the same labor characteristics as a man earns $11 \%$ less. In other words, a woman would need to work 40 extra days every year to make the same annual wages as a man with the same characteristics. At the same time, the simple difference in the average female vs. male wage in Serbia, i.e. the so-called raw (unadjusted) wage gap, amounts to only 3.3\%. Women's average wages at the level of the entire economy are "only" $3.3 \%$ lower than male. However, if there were no discrimination, women would earn more than men because they are better qualified. In Serbia, employed women have less work experience than men. The average years of experience for women are 15.9, while for men they are 18.1. Among clerks, women receive higher wages than men (by $4.4 \%$ ) and they take up the majority of all positions. The highest differences in wages (unadjusted gender wage gaps) can be found in low skill sectors: Agriculture, Industry and Traditional Services (12, 13.2 and 16.2\% respectively). In the private sector, women earn $9.4 \%$ lower wages than men. Women with tertiary education earn more than women with secondary and primary education Therefore, consistent with economic expectations, wages grow with the level of education, i.e. there are positive returns to education in Serbia. The true gender wage gap, which in Serbia stands at $11 \%$, is interpreted in economic literature as the effect of discrimination. The true gap mainly exists due to the different returns between men and women on unobserved characteristics. These could include differences in female and male labor market behavior which employers reward or punish within the same occupations and sectors of the economy, e.g. women may be less flexible in terms of working hours or business trips, due to home and reproductive responsibilities (Avlijaš et al., 2013).

Economic equality between women and men is essential to achieve a balance in relations between women and men. If they do not have equal conditions and opportunities for economic independence, all other measures to promote gender equality have less chance of success (National Strategy for improving the position of women and promote gender equality, article 4.2.2).

\section{CONCLUSION}

Although our analysis of key documents determines some progress in the field of gender equality related to economic independence, still much remains to be done to close gender gaps in economic empowerment, pay, earnings, pensions and 
power, and we all need to actively address stereotypes and participate in eradicating gender-based violence. Analyzing statistical data of economic independence through the employment rate, we have seen that the employment rate of men is greater than the employment rate of women and that women still wait for a job longer than men. According to the crucial European documents, in certain cases women and men are not paid the same wages although they carry out the same work or work of equal value. This gender pay gap may be the result of the so-called 'direct discrimination' where women are simply treated less favorably than men, certainly for various reasons. Women also work shorter hours and often part-time in order to combine their family responsibilities with paid work. Further, in most Member States, women continue to be under-represented in decision-making processes and positions, in particular at the highest levels, despite the fact that they make up nearly half the workforce and more than half of new university graduates in the EU.

According to the conducted research about the women in the labor market of the Republic of Serbia, the situation is quite the same as in the EU countries - the unemployment rate of women is a $50 \%$ higher than the unemployment rate of men. A gender pay gap is also expressed. A woman with the same labor characteristics as a man earns $11 \%$ less. There is a specific problem of employment of women over 45 years of age, as well as housewives, farmers, youth women, and women from discriminated groups. In the literature we can also find different data about what the reasons for discrimination against women when it comes to these two analyzed parameters -employment rate and gender pay gap, related to economic independence, and they are mostly related to a long absence of women from business due to maternity and other family responsibilities. The results summarized above confirm in particular the complex nature of gender equality and gender gaps in labor markets as multi-facetted social and economic phenomena. So it is essential to take some measures to reduce gender inequalities in the future. For successfully creating systemic prerequisites it is necessary to further amend the legislative framework and ensure the inclusion of all aspects of gender equality in development policies.

To establish a de jure and de facto equality between women and men in Serbia, of primary importance is the National Strategy for improving the position of women and promoting gender equality for the period 2009-2015. It established a state policy aimed at eliminating discrimination against women, improving their position and integration of gender equality in all areas of activity of the institutions. Therefore, it is necessary first to understand this matter, to perform extensive analyses, 
to incorporate the measures in the national policies through action plans and to introduce the population with their fundamental social rights. Only then it will be possible for both sexes with the same level of education to be treated equally at work and to be placed in certain high positions with the same level of salary for equal work. Otherwise gender equality in terms of economic independence is only a dead letter.

\title{
MEĐUNARODNI I DOMAĆI OKVIRI JEDNAKE EKONOMSKE NEZAVISNOSTI ŽENA I MUŠKARACA
}

\author{
Gardašević Jovana \\ Ignjatijević Svetlana
}

\begin{abstract}
Sažetak: Ekonomska nezavisnost omogućuje pojedincu kontrolu nad životom u cilju ličnog i profesionalnog prosperiteta. Princip jednakih zarada i jednakosti u radnom angažovanju je sadržan u EU sporazumima, odnosno jednakost je jedna od pet vrednosti na kojima počiva sistem vrednosti u EU. U radu smo pokusali da odgovorimo na pitanje da li se "jednaka plata za rad jednake vrednosti“ primenjuje i u praksi? Upravo iz tog razloga u ovom radu predmet istraživanja jeste analiza problema rodne nejednakosti sa ciljem da ukažemo na razlike u stopama zaposlenosti i visini zarada u Srbiji i zemljama EU. U radu smo analizirali ključna dokumenta, predložili mere i ukazali na strategije koje imaju za cilj da podrže i rešavaju pitanja rodne nejednakosti. U cilju izgradnje ekonomski i socijalno razvijenog drustva, Srbija na putu ka evropskim integracijama, treba da obrati posebnu pažnju na pitanje rodne ravnopravnosti, dodatno izmeni zakonski okvir i osigura ukljucivanje aspekata rodne ravnopravnosti u razvojne politike.
\end{abstract}

Ključne reči: rodna ravnopravnost / neravnopravnost polova / ekonomska nezavisnost / stopa zaposlenosti / jaz zarada

\section{REFERENCES}

1. Avlijaš, S., Ivanović, N., Vladisavljević, M., Vujić, S. (2013). Gender Pay Gap in the Western Balkan Countries: Evidence from Serbia, Montenegro and Macedonia, Beograd, FREN - Foundation for the Advacement of Economics.

2. Babcock L., Laschever, S. (2003). Women Don't Ask: Negotiation and the Gender Divide. Princeton, Princeton University Press. 
3. Becker, S. G. (1985). Human Capital, Effort, and the Sexual Division of Labor. Journal of Labor Economics, 3 (1), 33-58.

4. Bourgeais, V. (Ed.). (2015). Eurostat News Release: Employment rate of people aged 20 to 64 in the EU up to 69.2\% in 2014, Luxembourg, Eurostat Press Office.

5. Bourgeais, V. (Ed.). (2015). Eurostat News Release: Women earned on average 16\% less than men in 2013 in the EU, Luxembourg, Eurostat Press Office.

6. Chevalier, A. (2006). Education, Occupation and Career Expectation: Determinants of the Gender Pay Gap for UK Graduates, London, Center for the Economics of Education, London School of Economics

7. Commission of the European Communities (2015, April 20), Gender pay gaps in European labor markets-measurement, analysis and policy implications, Retrieved from:http://www.ispesl.it/dsl/dsl_repository/Sch39PDF08Marzo06/Sch39PayDiffGensec_03_937_en.pdf

8. European Commission (2015, April 20), A European Strategy for Smart, Sustainable and Inclusive Growth - Europe 2020, Retrieved from: http:// ec.europa.eu/eu2020/pdf/COMPLET\%20EN\%20BARROSO\%20\%20 \%20007\%20-\%20Europe\%202020\%20-\%20EN\%20version.pdf

9. European Commission (2015, April 20), Strategy for Equality between women and men 2010-2015, Retrieved from: http://ec.europa.eu/justice/gender-equality/files/strategy_equality_women_men_en.pdf

10. European Commission (2015, April 20), Commission Staff working document: Mid-term review of the Strategy for equality between women and men (2010-2015), Retrieved from: http://ec.europa.eu/justice/gender-equality/ files/strategy_women_men/131011_mid_term_review_en.pdf

11. European Commission (2015, May 16), Report on equality between women and men 2014, Retrieved from: http://ec.europa.eu/justice/gender-equality/files/annual_reports/150304_annual_report_2014_web_en.pdf

12. Groves Osborne, M., Gintis, H., Bowles, S. (2001). The Determinants of Earnings: A Behavioral Approach. Journal of Economic Literature, 39, 1137 1176.

13. Hussmanns, R., Mehran, F., Verma, V. (1990). Surveys of economically active population, employment, unemployment and underemployment: An ILO manual on concepts and methods, Geneva: ILO.

14. Kolin, M. (Ed.). (2009). Gender inequalities in the labor market of Serbia and European integration incentives, Belgrade, European Movement in Serbia.

15. Lazear, E. \& Sherwin, R. (1990) Male-Female Wage Differentials in job Ladders. Journal of Labor Economics, 8 (1), 106-123. 
16. Mincer, J. \&Polachek, S. (1974). Family Investments in Human Capital: Earnings of Women.Journal of Political Economy, 82 (2), 76-108.

17. Ministy of Labour, Employment, Veteran and Social Policy (2015, May 16), National Strategy for improving the position of women and promote gender equality 15/2009, Retrieved from: http://www.minrzs.gov.rs/files/doc/rodnaravnopravnost/dokumenta/Nacionalna_strategija_cir.pdf

18. Niederle M. \&Vesterlund, L. (2005). Do women shy away from competition? Do men compete too much?, National Bureau of Economic Research, WP11474.

19. Ombudsman (2015, May 16), The Gender Equality Law 104/2009, Retrieved from: http://www.ombudsman.rodnaravnopravnost.rs/attachments/013 ZAKON\%20O\%20RAVNOPRAVNOSTI\%20POLOVA.pdf

20. Radic, J. (2007). Economy Labor and Social Policy of the European Union, Subotica, Faculty of Economics.

21. Republic Institute for Statistics (2015, June 06), Women and Men in the Republic of Serbia 2014, Retrieved from:

22. http://webrzs.stat.gov.rs/WebSite/userFiles/file/Stanovnistvo/ZeneiMus/ ZiM_srpski_web.pdf

23. Republic Institute for Statistic (2015, June 06), Labor Force Survey I quarter, Retrieved from: http://webrzs.stat.gov.rs/WebSite/public/PublicationView.aspx ?pKey $=41 \&$ pLevel $=1 \&$ pubType $=2 \&$ pubKey $=2992$

24. Sijacki, V. (2008). European Union and Gender Equality, Novi Sad, Provincial Institute for Gender Equality.

25. Verloo, M. (2001). Another Velvet Revolution: Gender Mainstreaming and the Politics of Implementation, Vienna, IWM

26. Walby, S. (2005). Gender mainstreaming: Productive Tensions in Theory and Practice.Social Politics, 12 (3), 321-343.

27. Wood, G. R., Corcoran, E. M. and Courant, N. P. (1993). Pay Differences among the Highly Paid: The Male-Female Earnings Gap in Lawyers' Salaries. Journal of Labor Economics, 11 (3), 417-441.

28. Woodward, A. E. (2001). Gender Mainstreaming in European policy: innovation or deception?, Berlin, Social Science Research Center. 